\title{
PENGARUH PEMBERIAN MADU TERHADAP STAGING SPERMATOGENESIS DAN SEL LEYDIG PADA MENCIT (Mus musculus) YANG DIINFEKSI Toxoplasma gondii
}

\section{EFFECT HONEY IN SPREMATOGENESIS STAGING AND LEYDIG CELLS IN MICE (Mus musculus) INFECTED BY Toxoplasma gondii}

\author{
Paraswita Eindah Fitri ${ }^{1)}$, Wurlina $^{2)}$, Sri Chusniati ${ }^{3)}$, Lucia Tri Suwanti ${ }^{4}$, \\ Hani Plumeriastuti ${ }^{5}$, Mufasirin ${ }^{4}$ ) \\ ${ }^{1}$ Student, ${ }^{2)}$ Veterinary Reproduction Department, ${ }^{3)}$ Veterinary Bacteriology and Micology \\ Department ${ }^{4}$ Veterinary Parasitology Department, ${ }^{5}$ Veterinary Pathology Department \\ Faculty of Veterinary Medicine, Universitas Airlangga \\ email: paraswita.erindah.fitri@gmail.com; \\ *Corresponding author: email: wurlina_made@yahoo.co.id
}

\begin{abstract}
The aim of this research is to know about the staging of spermatogenesis and leydig cells in mice that injected by Toxoplasma gondii after giving honey as a preventive substance. This research used 25 mice in age 2-4 month with 20-30 weight. Mice were divided into 5 groups (P0, P1, P2, P3 dan P4). P0 as a control teratment were given aquades in peroral, P1 was a group given honey in doses $\mathrm{I}(0.08 \mathrm{ml} / 0.2 \mathrm{ml} /$ day $)$ during 14 days in peroral, $\mathrm{P} 2$ was a group that given infection by T.gondii in doses $10^{3}$ in peritonial, P3 was given honey in doses I $0.08 \mathrm{ml} / 0.2 \mathrm{ml} /$ day) then injected by $T$.gondii, and $\mathrm{P} 4$ was given honey in doses II $(0.12 \mathrm{ml} / 0.2 \mathrm{ml} /$ day $)$ then injected by T.gondii. This research conducted in 18 days, in day $14^{\text {th }}$ mice were given honey and the day $15^{\text {th }}-18^{\text {th }}$ mice injected by T.gondii doses $10^{3}$. The data result was analyzed with Analysis of Variant (ANOVA) and cotinued with Duncan. Comparision statistical showed with SPSS statistic 20 for Windows. The result of analysis, P0 and P1 were significantly different $(\mathrm{p}<0.05)$, with the increase number of spermatogenic and leydig cells. P0 and P2 also significantly different, with the decrease number of spermatogenic and leydig cells. In P2 and P3 group were not significantly different ( $\mathrm{P}>0.05)$, also in $\mathrm{P} 4$ group were not significantly different with $\mathrm{P} 0$ and $\mathrm{P} 1$. The results of this research showed that honey in doses II can maintain the number of sprematogenic and leydig cells as a preventive substance against $T$.gondii.
\end{abstract}

Key words : Honey, Toxoplasma gondii, testes.

\section{Pendahuluan}

Madu merupakan substansi alam yang diproduksi oleh lebah madu yang berasal dari nektar bunga atau sekret tanaman kemudian dikumpulkan oleh lebah madu, diubah dan disimpan di dalam sarang lebah untuk dimatangkan (Johnson and Nimisha, 2010). Madu dikenal sebagai cairan yang menyehatkan dan berkhasiat. Khasiat madu dikenalkan oleh Hippocrates yang memanfaatkan madu sebagai ekspetoran dan pembersih luka pada kulit maupun bisul (Rio dan Aziz, 2012). Salman et al., (2013), membuktikan bahwa penggunaan bahan yang mengandung chrysin dalam madu dapat meningkatkan fertilitas, hal ini dapat terlihat peningkatan jumlah sperma dan kadar hormon testosteron pada tikus albino jantan setelah pemberian madu secara peroral. Salah satu bahan yang mengandung chrysin adalah propolis yang merupakan produk asal lebah (Krell, 1996).

Yousef dan Salama (2009), menyatakan bahwa propolis dapat meningkakan proses steroidogenesis yang dibuktikan dengan meningkatnya produksi testosteron yang dihasilkan oleh sel Leydig. Peningkatan hormon testosteron membuktikan adanya pengaruh propolis terhadap fertilitas pejantan. Menurut Clermont dan Perey (2008), secara histologi fertilitas jantan dapat diukur melalui jumlah sel spermatogenik yang terdapat dalam tubulus seminiferus. Nugroho (2011), telah melakukan penelitian bahwa propolis meningkatkan staging spermatogenesis yang dibuktikan dengan meningkatnya jumlah sel sprematogenik. Staging spermatogenesis merupakan perkembangan siklus spermatogenesis di mana generasi sel germinal menjalani 
beberapa tahapan untuk menghasilkan spermatozoa. Staging spermatogenesis terdapat tiga tahap, yaitu spermatocytogenesis, meiosis, dan spermiogenesis (Ahmed and Dirk, 2009). Said (2013), telah membuktikan adanya penurunan jumlah sel spermatogenik yang telah diinfeksi Toxoplasma gondii.

Toxoplasma gondii merupakan parasit protozoa yang menyebabkan penyakit zoonosis yaitu toxoplasmosis. Toxoplasma gondii merupakan parasit intraseluler dengan hospes definitifnya adalah kucing dan hewan sejenisnya (Felidae) sedangkan hospes intermedietnya adalah semua hewan berdarah panas seperti ayam, kambing, babi dan sapi (Dubey et al., 1999). Manusia dan hewan dapat terinfeksi oleh $T$. gondii (Mufasirin dan Endang, 2013). Toxoplasma gondii mempunyai tiga stadium infektif yaitu takizoit, bardizoit dan ookista. Stadium takizoit ditemukan pada infeksi akut (Soedarto, 2008). Takizoit mampu berkembang biak hampir pada semua sel yang berinti termasuk sel sprematogenik (Chanon et al., 2000). Infeksi T. gondii mengakibatkan lesi histopatologi seperti adanya kongesti dan odema, disusul dengan perubahan retrogresif atau kemunduran sel yaitu perubahan regeneratif terhadap sel Leydig serta perubahan retrogesif dari sel spermatogenik pada testis (Khanif, 2012). Sampai saat ini belum ada laporan bahwa madu berpengaruh terhadap staging spermatogenesis dan sel Leydig yang diinfeksi $T$. gondii. Berdasarkan latar belakang di atas, maka perlu dilakukan penelitian pengaruh madu terhadap staging spermatogenesis dan sel Leydig pada mencit yang diinfeksi $T$. gondii.

\section{Metode Penelitian}

Sampel menggunakan mencit jantan jenis Swiss umur 2-3 bulan dengan berat badan 20-30 g dalam keadaan sehat. Besar sampel yang digunakan sebanyak 25 mencit. Penelitian ini dirancang dengan pola Rancangan Acak Lengkap (RAL). Terdapat lima perlakuan masing-masing dengan lima ulangan dibagi dengan cara random (Zainnudin, 2000). Mencit diadaptasikan selama tujuh hari dan diberi madu secara peroral selama 14 hari. Madu yang digunakan pada penelitian ini menggunakan madu Apis dorsata. Infeksi
T. gondii stadium takizoit dengan dosis $10^{3}$ disuntikkan secara intraperitoneal pada hari ke-15, pada hari ke-19 mencit dikorbankan dengan cara dislokasi leher dan diambil organ testis. Kelompok kontrol $\left(\mathrm{P}_{0}\right)$ yaitu mencit yang hanya diberi aquades. Kelompok perlakuan satu $\left(\mathrm{P}_{1}\right)$ yaitu mencit yang diberi madu dosis I $(0.08 \mathrm{ml} / 0.2 \mathrm{ml} /$ hari) selama 14 hari namun tidak diinfeksi $T$. gondii. Kelompok perlakuan dua $\left(\mathrm{P}_{2}\right)$ yaitu mencit yang tidak diberi madu namun diinfeksi $T$. gondii pada hari ke-15. Kelompok perlakuan tiga $\left(\mathrm{P}_{3}\right)$ yaitu mencit yang diberi madu dengan dosis I $(0.08 \mathrm{ml} / 0.2 \mathrm{ml} /$ hari $)$ selama 14 hari lalu pada hari ke-15 diinfeksi $T$. gondii. Kelompok perlakuan ke empat $\left(\mathrm{P}_{4}\right)$ yaitu mencit yang diberi madu dengan dosis II $(0.12 \mathrm{ml} / 0.2 \mathrm{ml} /$ hari) selama 14 hari lalu pada hari ke-15 diinfeksi $T$. gondii. Mencit yang telah dikorbankan diambil organ testis untuk dibuat preparat histopatologi dengan pewarnaan Hematoxylin Eosin (HE) yang selanjutnya akan diamati menggunakan mikroskop Nikon Eclipse C $i$ software DSU3. Data hasil jumlah sel spermatogenik dan sel Leydig pada testis mencit disajikan dalam $\mathrm{x} \pm \mathrm{SD}$, untuk melihat perbedaan perlakuan digunakan Analysis of Variant (ANOVA) pada tingkat kepercayaan 5\% (Kusriningrum, 2008). Apabila didapatkan perbedaan yang nyata di antara perlakuan maka dilanjukan dengan uji jarak Duncan. Analysis of Variant (ANOVA) maupun uji jarak Duncan dilakukan dengan menggunakan fasilitas SPSS versi 21 for Windows.

\section{Hasil dan Pembahasan Sel Spermatogenik}

Hasil pengamatan dan pengambilan data semua preparat histopatologi dilakukan menggunakan mikroskop pembesaran 400x. Hasil data menggunakan program Statistical Package for the Social Sciences (SPSS). Nilai rerata jumlah sel spermatogenik dari data penelitian dapat dilihat pada Tabel 1.

Analisis data menggunakan uji Analysis of Variance (ANOVA) dengan taraf kepercayaan 95\% untuk mengetahui adanya pengaruh antara dua kelompok perlakuan atau lebih. Hasil yang didapat pada jumlah sel spermatogenik adalah P0 sebanyak $1400.00 \pm 140.67$, P1 sebanyak $2117.80 \pm 184.96$, P2 sebanyak $1007.40 \pm$ 
138.21, P3 sebanyak $1112.20 \pm 247.98$ dan P4 sebanyak $1290.20 \pm 226.24$. Hasil tersebut menunjukkan adanya perbedaan sangat nyata $(\mathrm{p}<0.00)$. Hasil uji ANOVA dilanjutkan dengan menggunakan uji jarak Duncan terdapat perbedaan yang nyata $(\mathrm{p}<0.05)$ antara $\mathrm{P} 0$ dengan $\mathrm{P} 1, \mathrm{P} 2$ dan $\mathrm{P} 3$ dimana P0 dengan P1 mengalami perbadaan nyata dibuktikan dengan meningkatknya jumlah sel spermatogenik Kandungan propolis yang terdapat dalam madu dapat meningkatkan jumlah sel spermatogenik pada testis mencit (Mus musculus). Hasil penelitian ini sejalan dengan penelitian Nugroho (2011) yakni secara histopatologi pemberian madu yang mengandung propolis selama 14 hari menyebabkan peningkatan jumlah sel spermatogenik. Peningkatan jumlah sel spermatogenik oleh adanya kandungan crysin dan vitamin yang dapat meningkatkan hormon testosteron, Folicle Stimulating Hormone (FSH) dan Luteinizing Hormone (LH) (Holman, 1995; Friedl et al., 2000; Weinbauer et al., 2001). Ketiga hormon tersebut diperlukan pada proses spermatogenesis baik secara kuantitatif maupun kualitatif sehingga peningkatan hormon-hormon tersebut dapat memacu spermatogenesis (Holdcraft and Robert, 2004). Meningkatnya jumlah sel spermatogenik membuktikan bahwa terjadi peningkatan spermatogenesis, sehingga dapat diasumsikan bahwa terdapat dua mekanisme kerja dari propolis pertama, yaitu propolis berkerja merangsang langsung hipotalamus untuk menghasilkan Gonadotropin Releasing Hormon (GnRH) yang selanjutnya akan merangsang hipofisis anterior untuk mensintesis dan mensekresikan hormon FSH dan LH, kemudian hormon FSH dan LH menuju organ target untuk merangsang proses spermatogenesis. Kedua, propolis memiliki zat aktif yang mirip dengan $\mathrm{GnRH}(\mathrm{GnRH}$ like substance) yang merangsang hipofisis anterior untuk mensekresikan hormon FSH dan LH. Kedua hormon ini selanjutnya menuju organ target untuk merangsang spermatogenesis (Knobil, 2006).

Kelompok P0 dengan P2 mengalami perbedaan nyata dibuktikan dengan menurunnya jumlah sel spermatogenik. Infeksi $T$. gondii dosis $10^{3}$ dapat menurunkan jumlah sel spermatogenik pada testis. Penurunan jumlah sel spermatogenik dalam penelitian ini disebabkan oleh turunnya produksi hormon testosteron karena menurunnya jumlah sel Leydig. Penurunan inilah yang diyakini mengakibatkan gangguan pada staging spermatogenesis yang berujung pada menurunnya sel spermatogenik. Kelompok P2 yang diinfeksi T. gondii stadium takizoit dosis $10^{3}$ secara intraperitoneal tidak berbeda nyata $(\mathrm{p}>0.05)$ dengan kelompok P3 yakni kelompok madu dosis I $(0.08 \mathrm{ml} / 0.2 \mathrm{ml} /$ hari) secara peroral semalam 14 hari yang kemudian pada hari ke-15 diinfeksi $T$. gondii stadium takizoit dosis $10^{3}$ secara intraperitoneal selama lebih dari 4 hari. Pada kedua kelompok ini dapat didefinisikan bahwa dosis madu $0.08 \mathrm{ml} / 0.2 \mathrm{ml} /$ hari masih belum efektif untuk mempertahankan jumlah sel spermatogenik hingga seperti kelompok P0 atau kontrol. Berbeda halnya kelompok P4 dengan kelompok P0 atau kontrol yang menunjukkan hasil tidak berbeda nyata dibuktikan dengan susunan tubulus seminiferus dan jumlah sel spermatogenik yang hampir seperti kelompok P0 atau kontrol. Pada sel spematid kelompok P0, P2, P3 dan P4 tidak menunjukkan perbedaan nyata. Pada kelompok P2 yang diinfeksi $T$. gondii kemungkinan T.gondii menginfeksi sel pada bagian sitoplasma, sedangkan sel spermatid merupakan sel yang mempunyai sedikit sitoplasma karena spermatid sel merupakan sel yang akan berdeferensiasi menjadi spermatozoa. Hasil analis statistik perbedaan rerata jumlah sel spermatogenik dapat dilihat pada Tabel 1 dan Gambar 1.

\section{Sel Leydig}

Hasil pengamatan dan pengam-bilan data semua preparat histopatologi dilakukan menggunakan mikroskop pembesaran 400x. Hasil data menggu-nakan program Statistical Package for the Social Sciences (SPSS). Nilai rerata jumlah sel Leydig dari data penelitian dapat dilihat pada Tabel 2.

Analisis data menggunakan uji Analysis of Variance (ANOVA) dengan taraf kepercayaan 95\% untuk mengetahui adanya pengaruh antara dua kelompok perlakuan atau lebih. Hasil yang didapat pada jumlah sel Leydig adalah P0 sebanyak $14.44 \pm 7.93, \mathrm{P} 1$ sebanyak $17.60 \pm 4.63, \mathrm{P} 2$ sebanyak $7.92 \pm 0.92$, 
Tabel 1. Rerata data jumlah sel spermatogenik pada gambaran histologi testis mencit (Mus musculus) setiap perlakuan.

\begin{tabular}{ccccc}
\hline Perlakuan & $\begin{array}{c}\text { Jumlah sel } \\
\text { spermatogenik } \\
(\text { mean } \pm \text { SD) }\end{array}$ & $\begin{array}{c}\text { Jumlah sel } \\
\text { spermatogonium } \\
(\text { mean } \pm \text { SD })\end{array}$ & $\begin{array}{c}\text { Jumlah sel } \\
\text { spermatosit } \\
(\text { mean } \pm \text { SD) }\end{array}$ & $\begin{array}{c}\text { Jumlah sel } \\
\text { spermatid } \\
(\text { mean } \pm \text { SD })\end{array}$ \\
\hline P0 & $1400.00^{\mathrm{c}} \pm 140.67$ & $60.56^{\mathrm{b}} \pm 13.92$ & $101.08^{\mathrm{b}} \pm 22.54$ & $118.36^{\mathrm{a}} \pm 25.49$ \\
\hline $\mathbf{P 1}$ & $2117.80^{\mathrm{d}} \pm 184.96$ & $95.20^{\mathrm{c}} \pm 10.96$ & $156.52^{\mathrm{c}} \pm 39.45$ & $171.84^{\mathrm{b}} \pm 17.76$ \\
\hline $\mathbf{P 2}$ & $1007.40^{\mathrm{a}} \pm 138.21$ & $42.52^{\mathrm{a}} \pm 10.81$ & $53.92^{\mathrm{a}} \pm 8.42$ & $105.04^{\mathrm{a}} \pm 21.86$ \\
\hline $\mathbf{P 3}$ & $1112.20^{\mathrm{ab}} \pm 247.98$ & $48.40^{\mathrm{ab}} \pm 11.03$ & $56.80^{\mathrm{a}} \pm 7.17$ & $117.28^{\mathrm{a}} \pm 36.99$ \\
\hline $\mathbf{P 4}$ & $1290.20^{\mathrm{bc}} \pm 226.24$ & $58.20^{\mathrm{ab}} \pm 12.24$ & $79.24^{\mathrm{ab}} \pm 17.31$ & $120.60^{\mathrm{a}} \pm 33.76$ \\
\hline
\end{tabular}

Keterangan: Superkrip (a, b, c dan d) yang berbeda pada kolom yang sama menunjukkan perbedaan yang nyata $(\mathrm{p}<0,05)$.

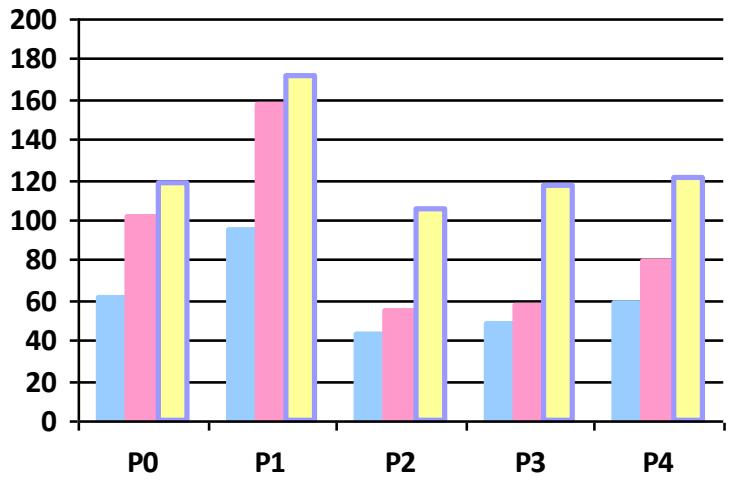

Gambar 1. Diagram jumlah sel spermatogenik mecit pada lima kelompok perlakuan yang berbeda.

Sel spermatogonium

Sel spermatosit

Sel spematid

P3 sebanyak $11.16 \pm 3.36$ dan P4 sebanyak $12.88 \pm 4.26$. Hasil tersebut menunjukkan tidak adanya perbedaan yang nyata $(p>0,05)$. Hasil uji ANOVA dilanjutkan dengan menggunakan uji jarak Duncan menunjukkan bahwa pada P0 tidak berbeda nyata dengan P1, P2, P3 dan P4. Pada P0 sel Leydig mengalami sedikit kenaikan dari $\mathrm{P} 1$, namun mengalami sedikit penurunan pada P2, P3 dan P4. Kelompok P1 menujukkan berbeda nyata $(\mathrm{p}<0.05)$ dengan P2 dibuktikan adanya penurunan sel Leydig. Diyakini peningkatan jumlah sel Leydig oleh adanya kandungan crysin dan vitamin yang dapat meningkatkan hormon testosteron, Folicle Stimulating Hormone (FSH) dan Luteinizing Hormone (LH) (Holman, 1995; Friedl et al., 2000; Weinbauer et al., 2001). Ketiga hormon tersebut diperlukan pada proses spermatogenesis baik secara kuantitatif maupun kualitatif sehingga peningkatan hormon-hormon tersebut dapat memacu spermatogenesis (Holdcraft and Robert, 2004). Hal ini berkesinambungan dengan meningkatnya jumlah sel spermatogenik dikarenakan di dalam testis LH merangsang sel interstisial untuk mensekresi testosteron yang diperlukan untuk pematangan akhir spermatozoa. Pembentukan testosteron sebanding dengan LH yang tersedia. Gangguan pada proses sekresi dan pengangkutan LH dan FSH yang terhambat dapat menganggu spermatogenesis. Hasil analis statistik perbedaan rerata jumlah sel Leydig dapat dilihat pada Tabel 2 dan Gambar 2.

Tabel 2. Rerata dari data jumlah sel Leydig pada gambaran histologi testis mencit (Mus musculus) setiap perlakuan.

\begin{tabular}{cc} 
Perlakuan & $\begin{array}{c}\text { Jumlah sel Leydig } \\
(\text { mean } \pm \text { SD })\end{array}$ \\
\hline 0 & $14.44^{\mathrm{ab}} \pm 7.93$ \\
\hline P1 & $17.60^{\mathrm{b}} \pm 4.63$ \\
\hline P2 & $7.92^{\mathrm{a}} \pm 0.92$ \\
\hline P3 & $11.16^{\mathrm{ab}} \pm 3.36$ \\
\hline P4 & $12.88^{\mathrm{ab}} \pm 4.26$
\end{tabular}

Keterangan: Superkrip (a, b, c dan d) yang berbeda pada kolom yang sama menunjukkan perbedaan yang nyata $(\mathrm{p}<0,05)$. 


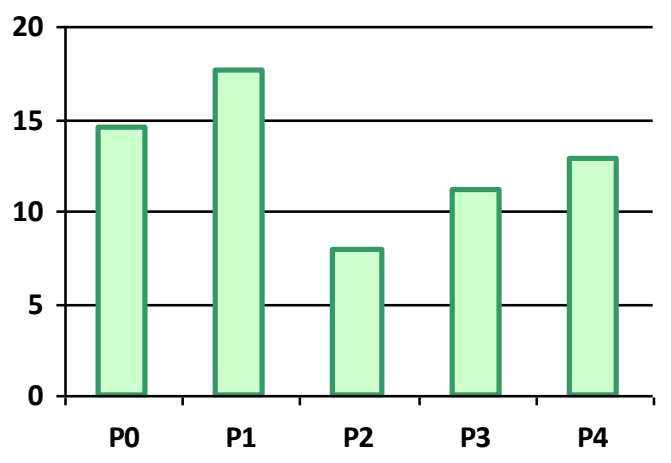

Sel Leydig

Gambar 2. Diagram jumlah sel Leydig mencit pada lima kelompok perlakuan yang berbeda.
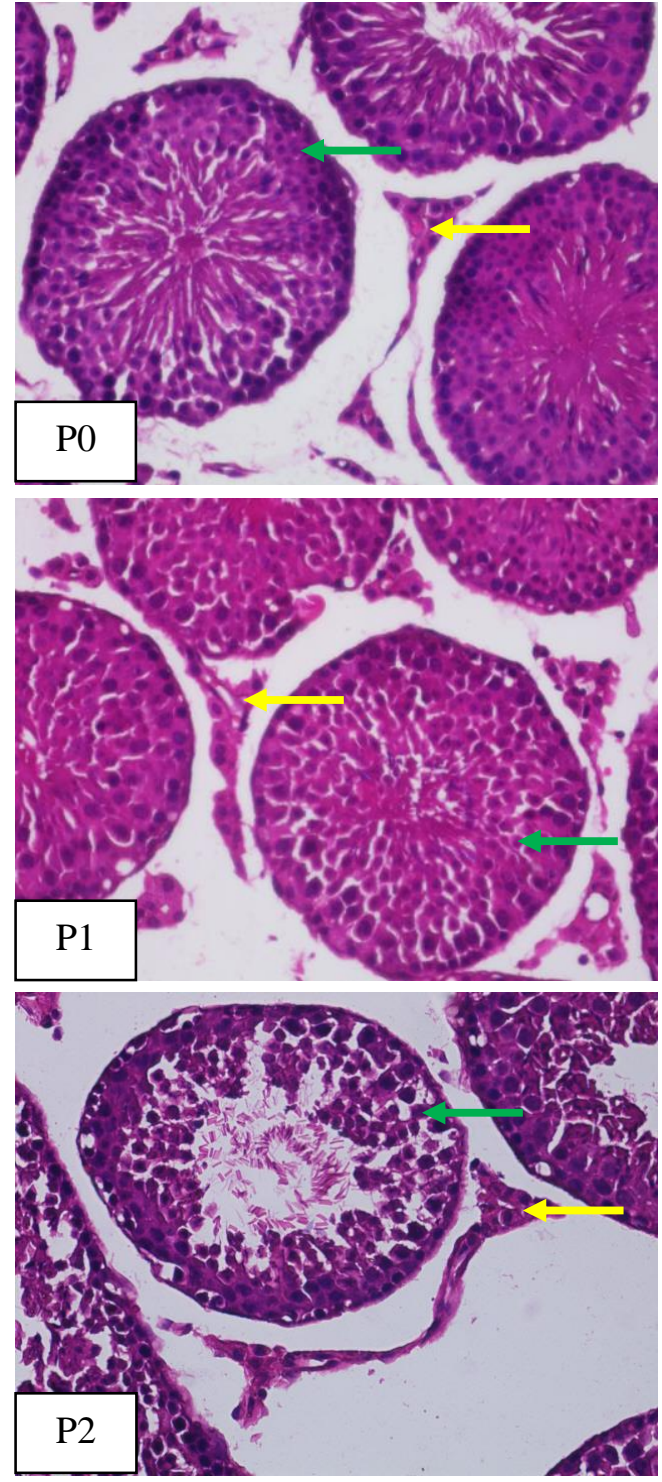
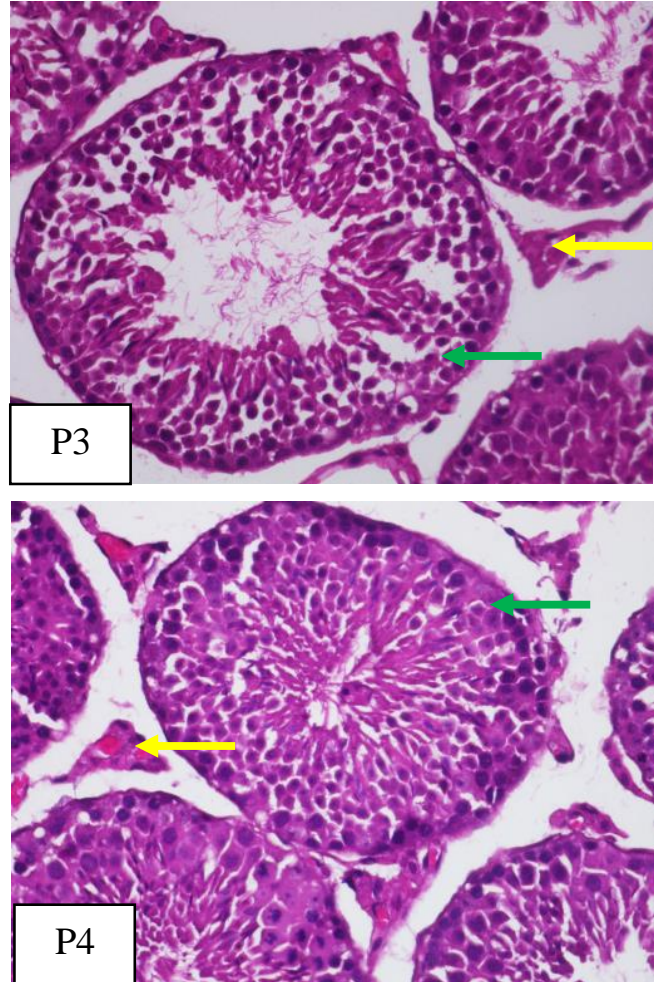

Gambar 3. Gambaran histopatologi perubahan jumlah sel spermatogenik dan sel Leydig testis mencit kelompok P0, P1, P2, P3, P4 perbesaran 400x dengan pewarnaan HE menggunakan mikroskop Nikon Eclipse C $i$ software DS-U3.

Tanda panah hijau $\rightarrow$ menunjukkan sel spermatogenik pada tubulus seminiferus dan tanda panah kuning menunjukkan sel Leydig pada intertitial tubulus semiferus. 

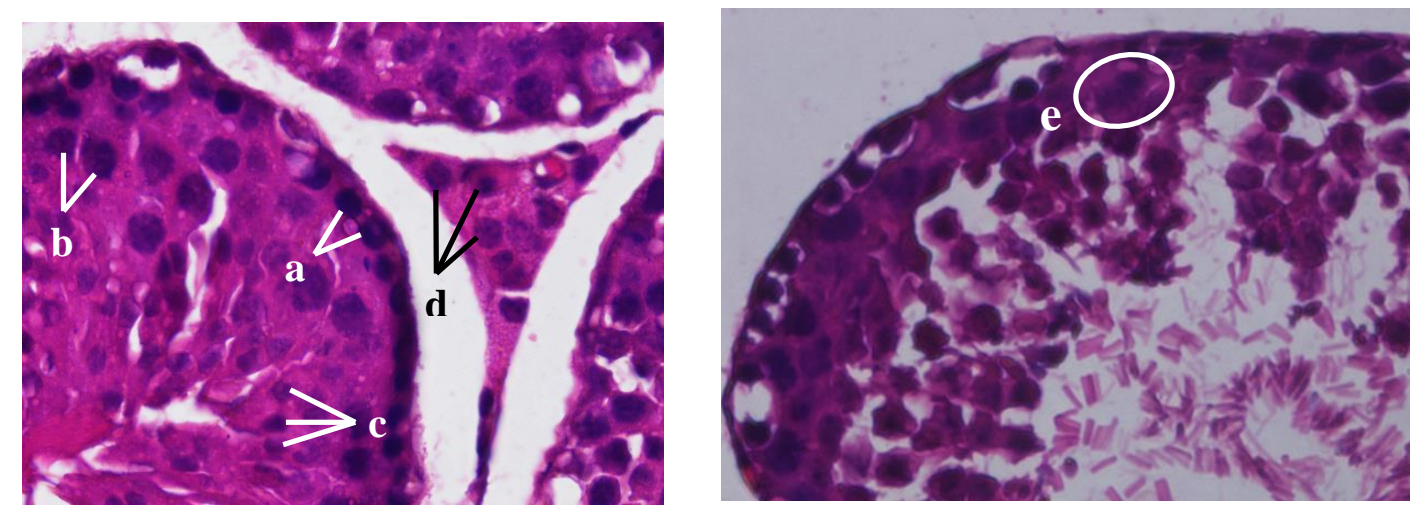

Gambar 4. Pada perbesaran 1000x terlihat (a) sel spermatogonium, (b) sel spermatosit, (c) sel spermatid, dan (d) sel Leydig. Pada kelompok P2 (e) sel spermatogenik terinfeksi T. gondii stadium takizoit dengan pewarnaan HE menggunakan mikroskop Nikon Eclipse Ci software DS-U3.

\section{Kesimpulan}

Berdasarkan hasil dari penelitian yang telah dilakukan maka dapat disimpulkan bahwa pemberian madu dengan dosis $0.08 \mathrm{ml} / 0.2 \mathrm{ml} / \mathrm{hari}$ masih belum efektif untuk mempertahankan staging sprematogenesis dan sel Leyding pada testis (Mus musculus) yang diinfeksi Toxoplasma gondii, sedangkan pemberian madu dengan dosis $0.12 \mathrm{ml} / 0.2 \mathrm{ml} /$ hari dapat mempertahankan staging spermatogenesis dan sel Leydig pada testis (Mus musculus) yang diinfeksi Toxoplasma gondii.

\section{Daftar Pustaka}

Ahmed, E. A. and D. G. De Rooij. 2009. Staging of Mouse Seminiferous Tubule Cross-Section. Scott Keeney. Humana Press Springer Science Busuness Media.

Chanon, J. Y., Seguin, R. M. and Kasper, L. H. 2000. Differential Infectivity and Division of Toxoplasma gondii in Human Peripheral Blood Leukocytes. Infect. Immunol. 68 : 4822-4826.

Clermont, Y. and Perey. 2008. Quantitive Study of the Cell Populaion of the Seminiferus Tubules in Immature Rats. The American Journal of Anatomy. 100 (2) : 353.

Dubey, J. P. 1999. Toxoplasma gondii. http://www.medimicrochapter84.html

Friedl, K. E., R. J. Moore, R. W. Hyot, L. J. Marchitelli, L. E. Martinez-Lopez and E. W. Askew. 2000. Endocrine Markers of Semistravvation in Healthy Lean Men in a Multistressor Enfironment. J Appl Phsiol. 88: 1820-1830.
Holdcraft, R. W and E. B. Robert. 2004. Hormonal Regulation of Spermatogenesis. International Journal of Andrology. 27: 335-342.

Holman P. 1995. Pyridoxine-Vitamin B6. J Autralian Collegue of Nutritionl and Enviromental Medicine. 14(1): 5-16.

Johnson S., and J. Nimisha. 2010. Antibiotic residues in honey. in: Center for Science and Enviroment. Tughlakabad Institusional Area. New Delhi.

Khanif. 2012. Gambaran Histopatologi Testis Mencit (Mus musculus) yang Diinfeksi Toxoplasma gondii [Skripsi]. Universitas Airlangga. Surabaya.

Knobil, E. 2006. Physiology of Reproduction. 3rd Ed, Elsevier Academic Press, Oxford. 223-224.

Krell, R. 1996. Value-Added Product of Bee Keeping. FAO Agricultural Services Bulletin No.124. Food and Agriculture Organization of the United Nations Rome.

Mufasirin, dan Endang S. 2013. Vaksininasi Protein Ekskretori-Sekretori Toxoplasma gondii Hasil Biakan in vivo Membangkitkan Respons Imun Non Protektif. Jurnal Veteriner. 14(1).

Nugroho, C. M. H. 2011. Potensi Propolis terhadap Jumlah Sel Spermatogenik, Sel Sertoli, Tebal Epitel dan Diameter Tubulus Seminiferus Testis Mencit (Mus musculus) [Skripsi]. Fakultas Kedokteran Hewan Universitas Airlangga. 
Rio,Y. dan Aziz, D. 2012. Perbandingan Efek Antibakteri Madu Asli Sikabu dengan Madu Lubuk Minturun terhadap Escherichia Coli dan Staphylococcus Aureus secara In Vitro. Jurnal Kesehatan Andalas. 1(2).

Said, M. 2013. Gambaran Histopatologi Testis Mencit (Mus musculus) yang Diinfeksi Toxoplasma gondii Stadium Takizoit Secara Oral [Skripsi]. Fakultas Kedokteran Hewan Universitas Airlangga. Surabaya.

Salman, T. M., L. A. Alagbonsi and L. A. Olayaki. 2013. Honey Increases Sperm Count in Male Albino Rats by Enhancing Testosterone Production. Journal of the Nigerian Society for Experimental Biology. 25(2): 39-44.
Soedarto. 2008. Parasitilogi Klinik. Airlangga University Press. Surabaya. Weinbauer, G. F., S. Schlatt, V. Walter and E. Nieschlag. 2001. TestosteronInduced Inhibition of Spermatogenesis is More Closely Related to Suppresion of FSH than to Testicular Androgen Levels in The Cynomulgus Monkey Model (Macaca fascicularis). Journal of Endocrinology. 168: 25-38.

Yousef, M. I. and A. F. Salama. 2009. Propolis Protection from Reproductive Toxicity of Triphenyltinin Male Rabbits. Food and Chemical Toxicology. 1646-1652.

Zainuddin, M. 2000. Metodologi Penelitian. Universitas Airlangga. Pasca Sarjana. 22-23. 